\title{
PENERAPAN MODEL PEMBELAJARAN KOOPERATIF JIGSAW DI STMIK YADIKA BANGIL PADA MATA KULIAH LOGIKA MATEMATIKA
}

\author{
Majida Noviyanti \\ Program Studi Teknik Informatika STMIK Yadika Bangil \\ opi.majida14@stmik-yadika.ac.id \\ Khusnul Khotimah \\ Program Studi Teknik Informatika STMIK Yadika Bangil \\ www.khusnul@stmik-yadika.ac.id
}

\begin{abstract}
Abstrak
Penelitian ini mendeskripsikan desain dan proses pembelajaran logika matematika di STMIK Yadika Bangil dengan menggunakan model pembelajaran kooperatif jigsaw serta memeriksa efektivitasnya. Hasil penelitian ini menunjukkan indikasi baik untuk semua aspek yang dievaluasi, yang meliputi motivasi, sikap mahasiswa terhadap pembelajaran kooperatif jigsaw, keterlibatan mahasiswa dalam pembelajaran, dan pencapaian mahasiswa yang dilihat dari penskoran terhadap hasil pengerjaan pre-test dan post-test yang dilakukan asesmen dengan menggunakan rubrik penskoran. Hasil pengerjaan pre-test menunjukkan akumulasi skor untuk keseluruhan mahasiswa sebesar 49, yang jika diubah dalam persentase yaitu $40,83 \%$. Setelah mengikuti pembelajaran materi inferensi logika dengan model kooperatif jigsaw, hasil pengerjaan post-test menunjukkan akumulasi skor keseluruhan mahasiswa sebesar 86 atau $71,67 \%$.
\end{abstract}

Kata kunci: jigsaw, pembelajaran kooperatif, logika matematika

\begin{abstract}
This study was held to describe design and process of mathematical logic learning in STMIK Yadika Bangil by using jigsaw cooperative learning model of instruction, and to check its implementation effectiveness. The result of this study showed positive marks for all the aspects that had been evaluated, which are consist of students' motivation, students' attitude toward the jigsaw cooperative learning, students' involvement in learning, and students' achievement. The students' achievement was evaluated by using the result of scoring toward students' pre-test and post-test. The scoring rubric was used in scale from one to four. The pre-test result showed accumulation score of 49 , or $40,83 \%$. After the instruction where the jigsaw cooperative learning was used, students' post-test accumulation score increased to 86 or $71,67 \%$.
\end{abstract}

Keywords: jigsaw, cooperative learning, mathematical logic 


\section{PENDAHULUAN}

Peran dosen pada era teknologi informasi berubah. Seperti yang dicantumkan oleh Jones dan Jones (2008) bahwa telah diprediksi oleh Duderstadt (1999), perguruan tinggi akan perlu untuk mengesampingkan peran sebagai pengajar dan menjadi designer pengalaman, proses, dan lingkungan belajar mahasiswa. Domingo (2008) menekankan pentingnya pembaruan dari metodologi pembelajaran tertentu pada konteks pendidikan tinggi, walaupun pada metodologi pembelajaran tersebut terdapat kesulitan-kesulitan dalam pelaksanannya (Jareño, 2014).

Di sisi lain, terdapat suatu kontradiksi mengenai perubahan paradigma pedagogis. Banyak perguruan tinggi di mana para pengajarnya tetap mengajar dengan pendekatan ceramah. Kritik mengenai pembelajaran kooperatif yaitu bahwa pembelajaran kooperatif lebih dimaksudkan untuk menjadi alternatif pendekatan pembelajaran, daripada untuk meningkatkan aktivitas proses perkuliahan (Paulson and Faust, 1998).

Dengan membandingkan hasil dari penelitian- penelitian yang berbeda mengenai pembelajaran kooperatif, penulis mencatat bahwa pembelajaran kooperatif menunjukkan pencapaian individu yang lebih besar daripada pembelajaran kompetitif and individualistik. Oleh karena itu, penulis bermaksud menerapkan teori pembelajaran kooperatif pada pembelajaran Logika Matematika di tingkat perguruan tinggi, yaitu di Sekolah Tinggi Manajemen Informatika dan Komputer (STMIK) Yadika Bangil.

Jigsaw merupakan salah satu jenis dari model pembelajaran kooperatif. Pada Longman Dictionary (1998), disebutkan bahwa Jigsaw mampu meningkatkan belajar siswa karena: 1) jigsaw tidak menekan peserta didik, 2) jigsaw meningkatkan partisipasi peserta didik di kelas, 3) jigsaw mengurangi rasa bersaing antara peserta didik, dan 4) jigsaw mengurangi dominasi pengajar di kelas. Pada akhirnya, jigsaw dapat mengurangi keengganan mahasiswa untuk berpartisipasi dalam aktivitas kelas dan membantu membangun suasana belajar yang terpusat pada diri mahasiswa.

Tujuan dari penelitian ini adalah untuk: (1) Mendeskripsikan desain pembelajaran logika matematika di STMIK Yadika Bangil dengan menggunakan model pembelajaran kooperatif jigsaw, (2) Mendeskripsikan 
proses pembelajaran logika matematika di STMIK Yadika Bangil dengan menggunakan model pembelajaran kooperatif jigsaw, dan (3) Memeriksa efektivitas implementasi model pembelajaran kooperatif jigsaw pada pembelajaran logika matematika di STMIK Yadika Bangil.

Kooperatif bermakna bekerja bersama untuk menyelesaikan tujuan yang sama. Dalam suasana kooperatif, masing-masing anggota mencoba hasil yang berguna bagi dirinya dan anggotanya (Johnson, Johnson, dan Smith, 2013). Pembelajaran kooperatif dapat didefinisikan sebagai suatu teknik pengelolaan kelas dimana peserta didik bekerja dalam aktivitas-aktivitas pembelajaran di kelompok-kelompok kecil dan menerima penghargaan berdasarkan hasil kerja kelompok mereka (Slavin dalam Rao, 2016). Pembelajaran kooperatif berbeda dengan kompetitif, dimana peserta didik saling melawan satu sama lain untuk memperoleh tujuan akademis, misal nilai A, yang hanya satu atau sedikit peserta didik dapat memperoleh. Pembelajaran kooperatif juga berbeda dengan pembelajaran individualistis, dimana peserta didik bekerja sendiri-sendiri untuk mencapai tujuan-tujuan belajar dan tidak berhubungan dengan proses belajar peserta didik lainnya (Johnson, Johnson, dan Smith, 2013).

Poin penting dari pembelajaran kooperatif adalah, semua peserta didik dalam kelompok berkontribusi untuk keuntungan sosial-akademis kelompok. Dengan peserta didik menjalankan pembelajaran secara kooperatif, cara seseorang dikatakan berhasil adalah jika seluruh anggota kelompok juga berhasil (Garfield, 2013). Dengan demikian, peserta didik saling mendukung satu sama lain untuk bekerja keras dan berjuang untuk prestasi maksimal bersama dan hubungan ini menjadi sikap dalam diri peserta didik.

Synder dan Lopez

(2007)

menyatakan bahwa pada pendekatan jigsaw, pengajar dan peserta didik memiliki tujuan-tujuan berbasis kelompok. Peserta didik dari latar belakang berbeda ditempatkan dalam satuan-satuan di mana mereka harus membagi informasi untuk kelompok, dan oleh karena itu untuk masing-masing anggota, agar berhasil (Rao, 2016). Slavin (1980) menyatakan bahwa dalam jigsaw, peserta didik ditempatkan dalam kelompok-kelompok kecil dan tugas 
dibagi dalam bagian-bagian dan ditujukan untuk anggota kelompok berdasarkan tingkat kemampuan (Rao, 2016).

Studi menunjukkan bahwa pada beberapa kondisi, pembelajaran kooperatif diharapkan lebih produktif daripada pembelajaran yang individualistis dan kompetitif. Johnson, Johnson, dan Holubec (dalam Mengduo dan Xiaoling, 2010) merumuskan lima prinsip untuk strategi jigsaw, yaitu: (1) Ketergantungan positif (positive interdependence); (2) Interaksi yang Membangun Secara Tatap Muka (Faceto-Face Promotive Interaction); (3) Pertanggungjawaban Individu dan Kelompok (Individual and Group Accountability); (4) Keterampilan Interpersonal (Interpersonal Skills), dan (5) Pengolahan Kelompok (Group Processing).

Ditinjau dari jenis datanya, penelitian ini menggunakan pendekatan penelitian kualitatif. Jenis penelitian ini adalah deskriptif, yaitu penelitian yang berusaha untuk menuturkan pemecahan masalah yang ada berdasarkan data-data. Penelitian ini bertujuan untuk mengetahui proses dan hasil dari pelaksanaan model kooperatif tipe jigsaw pada kelas mahasiswa jurusan teknik informatika
STMIK Yadika Bangil.

Subjek dalam penelitian ini adalah mahasiswa kelas A semester 1 tahun ajaran 2017 - 2018 program studi Teknik Informatika yang berjumlah 32 orang. Metode pengumpulan data yang digunakan dalam penelitian ini meliputi metode dokumentasi dan metode kuesioner. Berdasarkan teknik pengumpulan data yang digunakan, maka instrumen penelitian ini menggunakan: (1) soal pre-test, (2) lembar observasi kegiatan pembelajaran kooperatif tipe jigsaw, (3) soal post-test, dan (4) kuesioner. Soal pre-test dan post-test dalam penelitian ini adalah mengenai inferensi logika yang dikemas dalam bentuk soal cerita yang memuat pernyataan-pernyataan. Hasil pengerjaan soal pre-test dan post-test kemudian dilakukan asesmen dengan menggunakan rubrik. Kisi-kisi kuesioner pembelajaran kooperatif tipe jigsaw meliputi aspek: (1) Motivasi, (2) Pembelajaran kooperatif tipe jigsaw, dan (3) keterlibatan mahasiswa. Sedangkan untuk hasil kuesioner masing-masing pernyataan diberi skor menggunakan pedoman penskoran. 
HASIL DAN PEMBAHASAN

A. Desain Pembelajaran Logika Matematika di STMIK Yadika Bangil dengan Menggunakan Model Pembelajaran Kooperatif Jigsaw

Kegiatan pembelajaran dengan model kooperatif jigsaw dilakukan pada mata kuliah logika matematika khususnya pada materi inferensi logika. Pada perencanaan penelitian, pembelajaran dilakukan dengan langkah-langkah: (1) Memberikan materi kepada mahasiswa dengan media power point presentation; (2) Mengadakan pre-test secara individu kepada setiap mahasiswa;

Mengelompokkan mahasiswa. Karena dalam satu kelas terdapat 32 mahasiswa, maka mahasiswa akan dibagi ke dalam delapan kelompok, sehingga masingmasing kelompok memiliki empat orang anggota. Setelah terbentuk kelompok, mahasiswa menerima satu map yang berisi seperangkat kartu soal, lembar diskusi kelompok, dan lembar nama anggota kelompok; (4) Mahasiswa pada masing-masing kelompok memilih kartu soal yang menjadi bagiannya lalu mencermati soal sesuai instruksi dosen pengajar; (5) Mahasiswa berkumpul berdasarkan kesamaan nomor kartu soal. Pada tahap ini, akan terbentuk empat kelompok yang dinamakan kelompok ahli, yang masing-masing beranggotakan delapan orang. Dosen pengajar menginstruksikan masing- masing kelompok untuk duduk membentuk bundaran dengan terlebih dahulu menata meja dan kursi; (6) Mahasiswa kembali kepada kelompok asalnya masing-masing. Pada kelompok asal, mahasiswa menjelaskan hasil diskusinya yang telah dilakukan di kelompok ahli. Mahasiswa menjelaskan sambil menuliskan hasilnya pada lembar diskusi. Langkah ini dilakukan seterusnya sampai seluruh anggota selesai memberikan penjelasan di kelompok asal; (7) Dosen pengajar menyebutkan empat nama mahasiswa secara acak untuk masing-masing menjelaskan penyelesaian kartu soal 1,2, 3, dan 4 di depan kelas. Dosen memberikan konfirmasi jawaban; (8) Mahasiswa menerima post-test yang dikerjakan secara individu; Mahasiswa mengisi lembar kuesioner kemudian pembelajaran berakhir; (10) Dosen pengajar melakukan asesmen terhadap hasil post-test dengan memberikan skor sesuai skala rubrik. Kelompok yang terbaik adalah yang memiliki skor tertinggi. Penghargaan untuk kelompok terbaik yaitu dengan penambahan 5 pada skor ujian akhir. 
Pemberitahuan penghargaan kelompok terbaik disampaikan pada pertemuan berikutnya.

Sebelum melaksanakan pembelajaran, dilakukan kegiatan persiapan perangkat pembelajaran, antara lain rencana pelaksanaan pembelajaran, media berupa power point presentation mengenai inferensi logika, serta kartu soal inferensi logika. Selain perangkat pembelajaran, dosen pengajar juga mempersiapkan instrumen untuk penelitian, antara lain soal pre-test, soal post-test, lembar observasi aktivitas mahasiswa selama pembelajaran, dan lembar kuesioner untuk mahasiswa.

\section{B. Proses Pembelajaran Logika} Matematika di STMIK Yadika Bangil dengan Menggunakan Model Pembelajaran Kooperatif Jigsaw

Penelitian ini dilaksanakan dalam dua kali pertemuan. Pada pertemuan pertama, setelah salam dan melakukan presensi, dosen pengajar memberikan materi mengenai inferensi logika yang meliputi: (1) Hipotesis / premis / asumsi serta kesimpulan dari suatu argument; (2) Penentuan argumen yang dapat dikatakan sebagai argumen valid dengan menggunakan metode baris kritis dari tabel kebenaran; (3) Penentuan argumen yang dapat dikatakan sebagai argumen valid dengan menggunakan metode prinsip- prinsip inferensi logika; dan (4) Penentuan kesimpulan yang tepat dari sekumpulan premis untuk membentuk argumen valid dengan menggunakan inferensi logika dasar.

Selanjutnya, pada pertemuan kedua, setelah salam dan presensi, dosen pengajar terlebih dahulu mengingatkan mahasiswa mengenai materi inferensi logika pada pertemuan sebelumnya. Kemudian, dosen pengajar memberikan pre-test secara individu kepada mahasiswa. Pre-test dilaksanakan selama lima menit. Setelah pengerjaan pre-test selesai dan dikumpulkan, dosen pengajar memberikan penjelasan kepada mahasiswa bahwa pembelajaran hari ini mengenai soal-soal cerita inferensi logika yang dilakukan dengan metode kooperatif jigsaw. Dosen pengajar memberikan penjelasan mengenai langkah-langkah pembelajaran yang akan dilaksanakan.

Pembagian kelompok dilakukan oleh dosen pengajar berdasarkan nilainilai tugas mahasiswa, sehingga satu kelompok beranggotakan mahasiswa yang kemampuannya heterogen. Pada pelaksanaannya, terdapat dua mahasiswa yang tidak masuk sehingga dalam satu kelas terdapat tiga puluh mahasiswa. 
Dosen pengajar mengambil keputusan untuk membagi mahasiswa ke dalam tujuh kelompok dimana dua kelompok beranggotakan lima mahasiswa. Sehingga, pada dua kelompok ini, kartu soal nomor 4 dibebankan kepada dua mahasiswa, dengan dasar bahwa soal nomor 4 memiliki tingkat kesulitan yang lebih jika dibandingkan dengan soal-soal nomor 1 sampai 3. Mahasiswa kemudian berkumpul dengan kelompoknya masingmasing. Setelah semua kelompok siap, dosen pengajar membagikan map yang berisi seperangkat kartu soal, lembar penjelasan dan diskusi kelompok, serta daftar nama kelompok. Setelah masingmasing mahasiswa mengambil bagian tugasnya, mahasiswa yang memiliki bagian tugas yang sama kemudian berkumpul.

Kelompok ini disebut dengan kelompok ahli. Pada tahap ini, terdapat empat kelompok ahli yang berdiskusi menyelesaikan permasalahan pada kartu soal bagiannya. Proses diskusi kelompok ahli dapat dilihat pada Gambar 1 berikut.

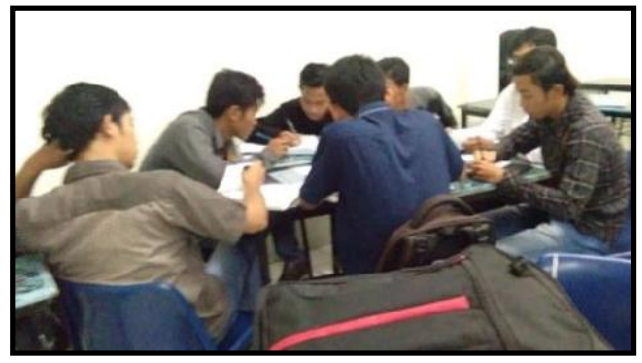

Gambar 1. Proses Diskusi Kelompok Ahli

Setelah dua puluh menit berdiskusi di kelompok ahli, mahasiswa kembali ke kelompok asal. Di kelompok asal, masing-masing anggota menjelaskan kepada anggota kelompoknya mengenai penyelesaian permasalahan pada kartu soal yang menjadi bagian tugasnya. Proses diskusi kelompok asal dapat dilihat pada Gambar 2 berikut.

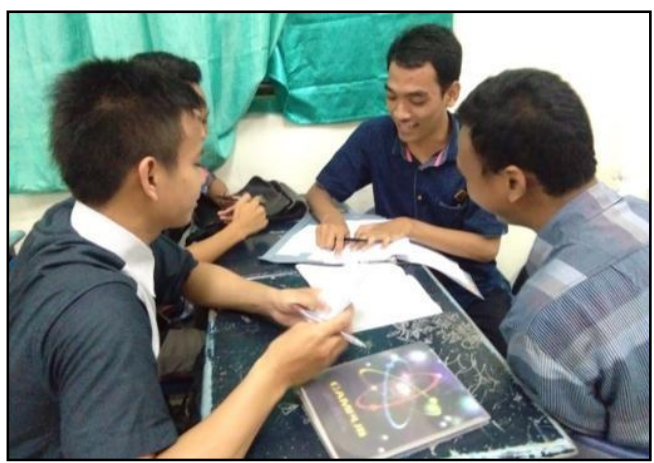

Gambar 2. Proses Diskusi di Kelompok Asal

Beberapa sampel hasil kerja mahasiswa di kelompok asal diambil. Gambar 3 berikut merupakan hasil penjelasan MHS 25 di kelompok 6 sebagai kelompok asalnya. 


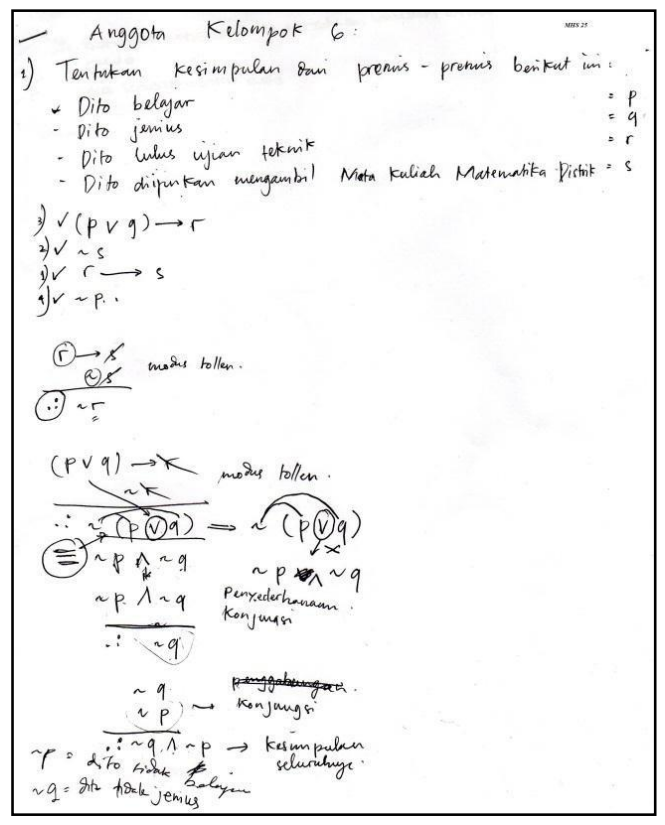

Gambar 3. Hasil Pengerjaan Kartu Soal 1 oleh MHS 25 di Kelompok 6

MHS 25 memiliki caranya sendiri untuk memahami prinsip inferensi modus tollen. Hal ini dapat dilihat ketika MHS 25 mengeliminasi $\boldsymbol{s}$ dan melingkari yang tidak tereliminasi yaitu $r$ dan tanda " $\sim$ lalu digabungkan sehingga diperoleh kesimpulan $\sim \boldsymbol{r}$. Kemudian, MHS 25 mengambil premis $(\boldsymbol{p} \vee \boldsymbol{q}) \rightarrow \boldsymbol{r}$ dan kesimpulan yang diperoleh sebelumnya $\sim \boldsymbol{r}$ serta menggunakan modus tollen. MHS 25 memperoleh kesimpulan $\sim(\boldsymbol{p} \vee \boldsymbol{q})$ dengan proses yang sama seperti sebelumnya, yaitu "eliminasi" dan "menggabungkan sisanya". Kesimpulan $\sim(\boldsymbol{p} \vee \boldsymbol{q})$ lalu diubah menjadi $\sim \boldsymbol{p} \wedge \sim \boldsymbol{q}$, namun tidak menuliskan Hukum De Morgan, melainkan dengan pemahamannya sendiri bahwa tanda negasi didistribuskan lalu tanda disjungsi berubah konjungsi. Dengan menggunakan prinsip inferensi penyederhanaan konjungsi, $\sim \boldsymbol{p} \wedge \sim \boldsymbol{q}$ disimpulkan $\sim \boldsymbol{q}$. MHS 25 lalu mengambil premis $\sim \boldsymbol{p}$ dan kesimpulan $\sim \boldsymbol{q}$ lalu memperoleh kesimpulan akhir $\sim \boldsymbol{p} \wedge \sim \boldsymbol{q}$ dengan prinsip inferensi konjungsi. Kesimpulan akhir ini lalu dikembalikan lagi ke pemisalan awal, yang berarti "Dito tidak belajar dan Dito tidak jenius".

Untuk penyelesaian kartu soal nomor 2, MHS 23 di kelompok 2 mengerjakan dan menjelaskan sesuai prosedur. MHS 23 terlebih dahulu menuliskan pemisalan dari setiap pernyataan tunggal yang diketahui, lalu mengubah premis-premis ke dalam bentuk pernyataan, menggunakan prinsip inferensi, dan memperoleh kesimpulan yang dikembalikan lagi ke pemisalan awal sehingga menjadi bentuk kalimat. Namun, MHS 23 tidak menuliskan Hukum De Morgan ketika menjelaskan $\sim \boldsymbol{r} \wedge \sim \boldsymbol{s}$ yang diubah menjadi $\sim(\boldsymbol{r} \vee \boldsymbol{s})$. Hasil pengerjaan dan penjelasan MHS 23 ini dapat dilihat pada Gambar 4 berikut. 


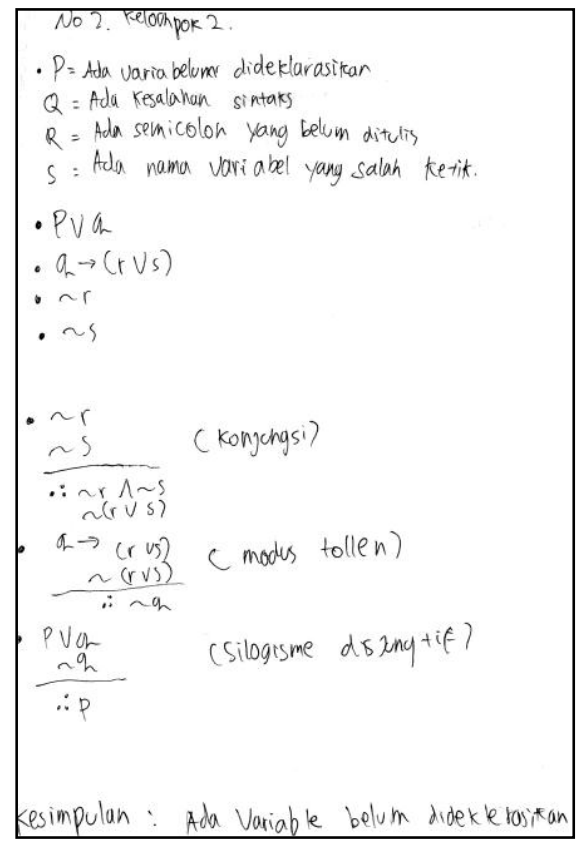

Gambar 4. Hasil Pengerjaan Kartu Soal 2 oleh MHS 23 di Kelompok 2

Untuk pengerjaan kartu soal nomor

3, MHS 12 di kelompok 2 melakukan sesuai prosedur. Yaitu melakukan pemisalan, mengubah premis menjadi bentuk pernyataan, melakukan proses inferensi sampai mendapatkan kesimpulan akhir, dan mengubah kesimpulan akhir menjadi bentuk kalimat. Namun dalam pemisalannya, MHS 12 menuliskan pemisalan setiap kalimat tunggal dengan masih menyertakan kata penghubung logika. Misalnya, $p$ untuk kalimat "Jika kacamataku ada di meja dapur". Kesimpulan akhir $t$ juga masih memuat kata penghubung logika, yang berbunyi "Maka pastilah kacamata kuletakkan di meja dapur". Mengetahui pengerjaan MHS 12 ini, dosen pengajar kemudian memberikan penegasan bahwa untuk melakukan pemisalan, tidak perlu menyertakan kata penghubung logika seperti "jika-maka". Hasil pengerjaan MHS 12 ini dapat dilihat pada Gambar 5 berikut.

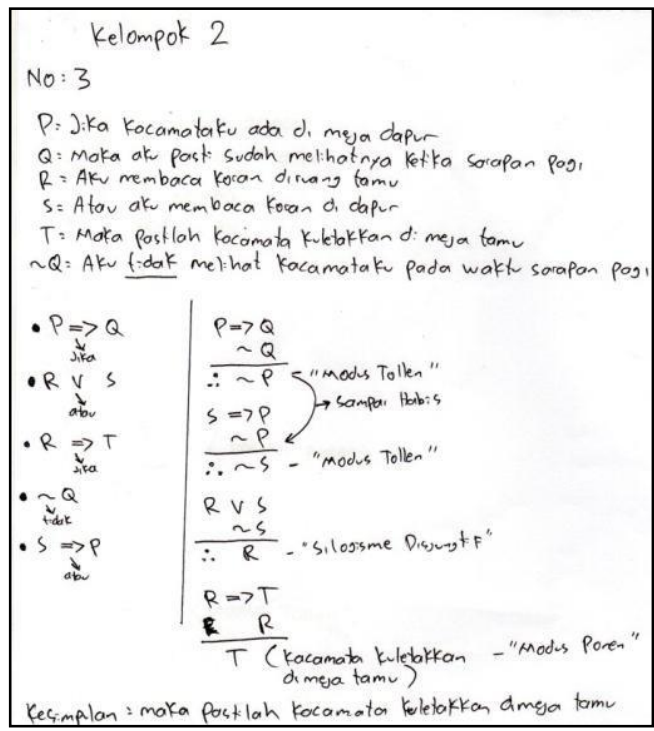

Gambar 5. Hasil Pengerjaan Kartu Soal 3 oleh MHS 12 di Kelompok 2

Pada pengerjaan kartu soal nomor 4, MHS 28 di kelompok 3 melakukan sesuai dengan prosedur. Namun, MHS 28 menulis "statemen" untuk menyatakan "bentuk pernyataan" dari premis yang diketahui, serta penyusunannya seperti argumen yang berisi premis-premis dan kesimpulan yang ditulis dengan simbol tanda tanya. Hasil pengerjaan MHS 28 dapat dilihat pada Gambar 6 berikut. 


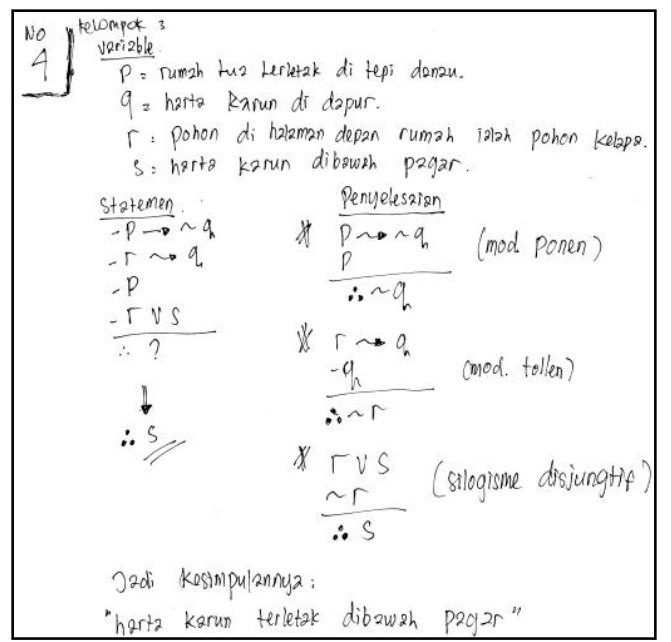

Gambar 6. Hasil Pengerjaan Kartu

Soal 4 oleh MHS 28 di Kelompok 3

Setelah semua mahasiswa dalam kelompoknya selesai menjelaskan penyelesaian soal bagiannya, dosen pengajar memanggil empat nama mahasiswa secara acak untuk mengkonfirmasi jawaban. Kemudian dosen pengajar menyimpulkan materi pembelajaran sebagai penguatan dan memberikan post-test. Setelah post-test selesai dilakukan, dosen pengajar membagikan kuesioner kepada mahasiswa, lalu mengakhiri pembelajaran dengan mengucapkan salam.

\section{Efektivitas Implementasi Model Pembelajaran Kooperatif Tipe Jigsaw pada Pembelajaran Logika Matematika di STMIK Yadika Bangil}

Peneliti merumuskan aspek-aspek untuk menentukan tingkat efektivitas implementasi model pembelajaran kooperatif jigsaw pada pembelajaran logika matematika materi inferensi logika. Aspek-aspek tersebut antara lain sebagai berikut.

1. Motivasi mahasiswa selama mengikuti pembelajaran

Pada aspek motivasi, terdapat tiga indikator yang diukur dalam penelitian ini, yaitu: (1) persiapan mahasiswa, (2) memperhatikan penjelasan dosen dan rekan, dan (3) mengerjakan tugas yang diberikan secara sungguh-sungguh, baik individu maupun kelompok.

Dari hasil kuesioner, sebanyak $77,5 \%$ mahasiswa membaca materi selama mengikuti pembelajaran inferensi logika dengan menggunakan metode jigsaw. Berdasarkan Tabel 4 Pedoman Hasil Evaluasi, hasil ini dikategorikan baik. Indikator mengenai tingkat perhatian mahasiswa terhadap penjelasan dosen dan rekan juga menunjukkan hasil yang baik. Dari hasil kuesioner menunjukkan sebesar $86,67 \%$ sedangkan observasi pengamat menunjukkan $76,67 \%$. Untuk indikator mengenai kesungguhan mahasiswa dalam mengerjakan tugas selama pembelajaran, hasil kuesioner menunjukkan 79,17\%. Dari hasil 
observasi pengamat, $\quad 76,67 \%$ mahasiswa menunjukkan keseriusan saat berdiskusi dalam kelompok ahli dan $74,17 \%$ mahasiswa menunjukkan keseriusan saat berdiskusi dalam kelompok asal.

2. Sikap mahasiswa terhadap pembelajaran kooperatif tipe jigsaw

Sikap mahasiswa terhadap pembelajaran yang diukur dalam penelitian ini meliputi: (1) antusiasme dalam memecahkan permasalahan pada kartu soal, (2) peningkatan semangat belajar, (3) peningkatan pemahaman materi, dan (4) tingkat sikap positif terhadap pembelajaran.

Hasil kuesioner menunjukkan $80 \%$ mahasiswa berusaha menguasai materi secara mendalam melalui berlatih memecahkan masalah dalam kartu soal. Sedangkan hasil observasi pengamat menunjukkan $75,83 \%$ mahasiswa antusias dalam menerima kartu soal. Hasil ini menunjukkan bahwa antusiasme mahasiswa terhadap kartu soal dikategorikan baik. Untuk indikator peningkatan semangat belajar, $82,5 \%$ mahasiswa menyatakan semangat belajarnya meningkat ketika mengikuti pembelajaran kooperatif jigsaw. Dari hasil kuesioner juga diketahi bahwa $85 \%$ mahasiswa menyatakan lebih mudah mempelajari inferensi logika dengan pembelajaran kooperatif tipe jigsaw. Selain itu, $80,83 \%$ mahasiswa menyatakan senang saat belajar inferensi logika dengan model kooperatif tipe jigsaw. Dari data- data tersebut, dapat disimpulkan bahwa sikap mahasiswa terhadap pembelajaran kooperatif tipe jigsaw sangat baik.

3. Keterlibatan mahasiswa dalam pembelajaran

Untuk mengevaluasi keterlibatan mahasiswa dalam pembelajaran, terdapat tiga indikator yang dikembangkan, yaitu: (1) mengikuti jalannya diskusi dengan sepenuh hati dan tanggung jawab, (2) menerima dan mencatat hal-hal penting yang telah disampaikan dosen atau rekan, dan (3) menerima dengan puas hasil belajar yang dicapai.

Dari hasil kuesioner, diketahui $81,67 \%$ mahasiswa menyatakan aktif dalam diskusi kelompok, baik dalam kelompok ahli maupun kelompok asal. Sedangkan dari observasi pengamat, 75,83\% mahasiswa menunjukkan sikap bertanggung jawab atas tugasnya yaitu menyampaikan hasil diskusi yang 
diperoleh dari kelompok ahli kepada teman kelompok asalnya. Diketahui pula sebesar $80 \%$ mahasiswa menyatakan menerima dan mencatat penjelasan dari dosen dan teman selama diskusi. Mengenai kepuasan hasil belajar, 73,33\% mahasiswa menyatakan puas dengan hasil belajar yang dicapai dalam pembelajaran inferensi logika dengan pembelajaran kooperaif jigsaw. Jadi, dapat disimpulkan bahwa keterlibatan mahasiswa dalam pembelajaran dikategorikan baik.

4. Pencapaian mahasiswa setelah mengikuti pembelajaran

Pencapaian mahasiswa dilihat dari penskoran terhadap hasil pengerjaan pre-test dan post-test. Hasil pengerjaan pre-test menunjukkan akumulasi skor untuk keseluruhan mahasiswa sebesar 49, yang jika diubah dalam persentase yaitu 40,83\%. Berdasarkan Tabel 4, hasil ini dikategorikan kurang. Setelah mengikuti pembelajaran materi inferensi logika dengan model kooperatif jigsaw, hasil pengerjaan post-test menunjukkan akumulasi skor keseluruhan mahasiswa sebesar 86 atau $71,67 \%$ yang termasuk dalam kategori baik.

\section{PEMBAHASAN}

Menurut Johnson, Johnson, dan Smith (2013), pembelajaran kooperatif merupakan pembelajaran yang melibatkan siswa bekerja dalam kelompok untuk mencapai tujuan bersama, di bawah kondisi yang melibatkan lima elemen. Pada penelitian ini, peneliti mencoba mencapai kelima elemen tersebut dengan cara sebagai berikut.

1. Saling Ketergantungan Positif (Positive Interdependence)

Pada pembelajaran kooperatif tipe jigsaw, mahasiswa dalam satu kelompok memiliki ketergantungan satu sama lain. Mereka harus menyusun penyelesaian dari empat kartu soal. Satu anggota bertanggung jawab untuk satu kartu soal. Selain itu, pemahaman bersama penting untuk dibangun dalam kelompok. Sebab, akumulasi skor post-test individu akan mempengaruhi apakah kelompok akan memperoleh penghargaan. Sehingga, satu mahasiswa tidak akan bisa berhasil mencapai tujuan bersama jika tidak dengan mahasiswa lainnnya dalam satu kelompok.

2. Pertanggungjawaban Individu (Individual Accountability)

Setiap anggota kelompok 
bertanggung jawab atas pemahaman dan penyelesaian kartu soal masingmasing. Sebab, setelah diskusi kelompok ahli, mereka akan kembali ke kelompok asalnya untuk menjelaskan penyelesaian kartu soalnya, yang sebelumnya didiskusikan di kelompok ahli. Jadi, setiap individu dalam kelompok memiliki tanggung jawab masingmasing.

3. Keahlian Interpersonal (Appropriate Use of Social Skills)

Dalam pembelajaran, kerja kelompok akan efektif jika setiap anggota mau melibatkan diri dalam proses diskusi yang membangun. Selama proses pembelajaran, dosen pengajar memantau setiap kelompok. Setiap ada anggota kelompok yang kurang berpartisipasi dalam kelompok, dosen pengajar selalu mengingatkan. Begitu juga jika ada mahasiswa dalam satu kelompok yang saling beradu pendapat, dosen pengajar menjadi pihak penengah. Dengan demikian, mahasiswa dapat berlatih membangun keterampilan dalam bersosial.

4. Interaksi yang Membangun Secara Tatap Muka (Face-to-Face Promotive Interaction)
Penataan meja dan kursi dalam pembelajaran ini mendukung adanya interaksi dengan bertatap muka. Saat diskusi kelompok ahli, mahasiswa berinisiatif dengan sendirinya untuk memindah empat meja untuk didekatkan sehingga memudahkan diskusi dengan tatap muka. Demikian pula saat kembali ke kelompok asal, mahasiswa mendekatkan dua meja dan duduk berhadap-hadapan. Saat satu anggota dalam kelompok mendapat giliran menjelaskan, maka anggota lain memperhatikan. Jadi, pembelajaran kooperatif tipe jigsaw mendukung adanya interaksi secara tatap muka.

5. Pengolahan dalam Kelompok (Group Processing)

Selama proses pembelajaran, keterampilan sosial mahasiswa terus dilatih. Dengan pengamatan dosen pengajar, setiap kali ada mahasiswa yang tidak menunjukkan keterampilan sosialnya, maka dosen pengajar akan menegur dan memberi dorongan. Apabila setiap anggota dalam satu kelompok telah menunjukkan keterampilan sosial yang baik, dosen pengajar akan memberikan pujian, seperti "Good, sudah kompak kelompok kalian!” misalnya. 
Dengan pembelajaran kooperatif tipe jigsaw, pembelajaran akan menjadi lebih interaktif dan seluruh mahasiswa akan terlibat dalam pembelajaran. Jolliffe (2007) menyatakan bahwa ada dua alasan pembelajaran kooperatif lebih interaktif, yaitu sebagai berikut.

\section{Secara motivasi}

Langkah-langkah pembelajaran kooperatif menciptakan situasi dimana anggota kelompok hanya dapat menuntaskan tugas apabila anggota lain dapat berpartisipasi. Sehingga, peserta didik termotivasi untuk mencoba dan belajar sungguh-sungguh untuk dapat mendukung kelompoknya. Keadaan ini merupakan suatu transformasi, dari keadaan dimana peserta didik berkompetisi satu sama lain menjadi keadaan dimana peserta didik belajar sungguh-sungguh yang hasilnya dapat membantu peserta didik lainnya.

2. Secara kognitif

Peserta didik yang bekerja secara kooperatif menunjukkan perkembangan intelektual karena mereka saling mendukung satu sama lain dalam pembelajaran. Lebih jauh lagi, teori perluasan kognitif menyatakan bahwa, jika suatu informasi tertahan, maka restrukturisasi kognitif perlu dilakukan, seperti menggunakan informasi ke dalam format atau katakata yang berbeda. Salah satu cara yang efektif untuk melakukan restrukturisasi kognitif ini adalah dengan menjelaskan informasi tersebut kepada orang lain, yang merupakan bagian aktivitas dalam pembelajaran kooperatif jigsaw.

\section{SIMPULAN}

Pembelajaran Inferensi Logika pada mata kuliah Logika Matematika dilaksanakan dalam dua pertemuan. Seluruh mahasiswa terlibat dalam dua macam proses diskusi, yaitu diskusi kelompok ahli dan diskusi kelompok asal. Pembelajaran kooperatif tipe jigsaw yang telah dilaksanakan memenuhi lima elemen pembelajaran kooperatif yang dirumuskan oleh Johnson, Johson, dan Smith (2013). Pembelajaran yang dilakukan juga dikatakan efektif untuk dilaksanakan dalam setting perguruan tinggi. Dapat dilihat dari aspek dan indikator penilaian yang semuanya masuk dalam kategori baik. Aspek-aspek yang telah dinilai baik dalam penelitian ini meliputi: (1) motivasi mahasiswa selama mengikuti pembelajaran, (2) sikap mahasiswa terhadap pembelajaran kooperatif tipe 
jigsaw, (3) keterlibatan mahasiswa dalam pembelajaran, dan (4) peningkatan pencapaian mahasiswa setelah mengikuti pembelajaran.

\section{DAFTAR PUSTAKA}

Garfield, Joan. 2013. Cooperative Learning Revisited: From an Instructional Method to a Way of Life. Journal of Statistics Education, Volume 21, Number 2.

Jareno, F., Jiménez, J. J., Lagos, M.G. 2014. Cooperative Learning in Higher Education: Diffrences in Perceptions of Contribution to The Group. Revista de Universiad y Sociedad del Conocimiento Universities and Knowledge Society Journal. Vol. 11 No. 2.

Johnson, D.W., Johnson, R.T. and Smith, K. (2013). Cooperative Learning: Improving University Instruction by Basing Practice on Validated Theory. In: Davidson, N., Major, C. and Michaelsen, L., Eds., SmallGroup Learning in Higher Education: Cooperative, Collaborative, Problem-Based and Team-Based Learning. Journal on Excellence in College Teaching, 25(4).

Johnson, D.W., Johnson, R.T. 2014. Cooperative Learning in 21st Century. In: anales de psicologia. Vol. 30, pp. $841-851$.

Jolliffe, Wendy. 2007. Cooperative Learning in The Classroom: Putting It into Practice. London: Paul Chapman Publishing.

Jones, K. A., \& Jones, J. L. 2008. Making Cooperative Learning Work in The
College Classroom: An Application of The "Five Pillars" of Cooperative Learning to PostSecondary Instruction. The Journal of Effective Teaching, Vol. 8, No. 2, 2008, $61-76$.

Longman Dictionary of Language Teaching and Applied Linguistics. 1998. Longman Group UK Limited.

Mengduo, Q., Xiaoling, J. 2010. Jigsaw Strategy as a Cooperative Learning Technique: Focusing on the Language Learners. Chinese Journal of Applied Linguistics Vol. 33 No. 4.

Paulson, D.R., \& Faust, J.L. 2008. Active Learning for the College Classroom. Diakses April 2017 dari http://www.calstatela.edu/dept/che $\mathrm{m} /$ chem2/Active/main.htm

Rao, Venkateshwar. 2016. Understanding Jigsaw Cooperative Learning: Influence on Scholastic Achievement and Learning Experiences of Students in Mathematics Education. The International Journal of Indian Psychology. Volume 3, Issue 3, No. 4.

Siang, Jong Jek. 2014. Logika Matematika: Soal dan Penyelesaian Logika, Himpunan, Relasi, Fungsi. Yogyakarta: Penerbit ANDI. 
Noviyanti dan Khotimah, Penerapan Model... 